\title{
Methylmalonic aciduria due to transcobalamin receptor defect
}

INSERM

\section{Source}

INSERM. (1999). Orphanet: an online rare disease and orphan drug data base. Methylmalonic aciduria due to transcobalamin receptor defect. ORPHA:280183

Methylmalonic aciduria due to transcobalamin receptor defect is a rare metabolite absorption and transport disorder characterized by a moderate increase of methylmalonic acid (MMA) in the blood and urine due to decreased cellular uptake of cobalamin resulting from decreased transcobalamin receptor function. Patients are usually asymptomatic however, screening reveals increased C3-acylcarnitine and MMA in plasma. Serum homocysteine levels may vary from normal to moderately elevated and retinal vascular occlusive disease, resulting in severe visual loss, has been reported. 